\title{
CoInTEGration ANd STOCK MARKET INTERDEPENDENCE: EVIDENCE FROM SOUTH AFRICA, INDIA AND THE USA
}

\author{
Thangamuthu Mohanasundaram and Parthasarathy Karthikeyan \\ School of Management Studies, Kongu Engineering College \\ Accepted: May 2015
}

\begin{abstract}
The purpose of this study is to explore the nature of the association and the possible existence of a shortrun and long-run relationship between the stock-market indices of South Africa, India and the USA. The idea behind this combination is to know how the stock markets of these three prominent countries are related to each other. The study employs monthly data from the stock indices, namely JALSH (South Africa), NIFTY (India) and NASDAQ (USA) composite from April 2004 to March 2014. After testing for the normality of the data distribution and the stationarity of the time series data, this paper discovered a strong correlation between the stock market indices of South Africa, India and the USA. The correlation among the stock markets is high, particularly between South Africa and India. In addition, the paper attempts to discover the presence of any predictive ability among these markets by applying the Granger causality test. The result indicates that the NASDAQ index has no predictive ability as far as the JALSH and NIFTY indices are concerned. However, the JALSH index has a predictive ability on the NIFTY index. After testing the Granger cause relationship, the existence of a long-run and short-run relationship is tested. The long-run relationships among the stock market indices are analysed, following the Johansen and Juselius multivariate cointegration approach. The result suggests the absence of a long-run relationship among the three stock market indices. Short-run relationship is investigated with the Vector Autoregression (VAR) model, and the outcome obtained shows that both the USA and the South African stock markets are predicted only by their own past lags. However, the Indian stock market is seen to be a function of its own past lags and the past lags of the South African stock index.
\end{abstract}

Key words: stock market, correlation; Granger causality, cointegration; vector autoregression

JEL: G15, C32

\section{$1 \quad$ Introduction}

Globalization has gained momentum over the past two decades. Financial markets are at the forefront of this development. In 2013, the global market capitalization increased significantly to USD 64 trillion (17 per cent growth rate) and the value of share trading increased to USD 55 trillion (12 per cent growth rate) ${ }^{1}$. Development in multinational companies, advances in information technology, deregulation of financial systems, growth in international capital flows and abolishment of foreign exchange control have increased cross-country correlation, bringing nations together economically (Tehrani, 2011). The movement towards enhanced earnings and portfolio diversification makes way for a worldwide capital movement in the form of both direct and portfolio investments, which ultimately leads to stock market integration. On the other hand, inter-linkages among stock markets may bring different risks, such as the contagion effect and ripple effects of economic events in distant countries. These were evidenced during the 2008 subprime credit market crisis in the USA. It is therefore of great academic and practical importance to understand the linkages between the different world stock markets.

Several researchers have studied the determinants and relationships among various equity markets across the world (Ekaterina Dorodnykh, 2014; Janak Raj \& Sarat Dhal, 2008; Andjelic \& Djakovic, 2012; Raja Sethu Durai \& Bhaduri, 2011). Many regional studies have been undertaken in the European, Middle-East and Gulf, Asian and African markets. There are also numerous of studies connecting regional and global markets. Even though many studies on stock market integration are available, the researchers have not encountered any relating to the cointegration of the South African, Indian and USA stock markets. 
This study examines the mutual relation among the three stock markets of South Africa, India and the USA. We investigate the trilateral associations of these three stock markets because the USA market is the most developed, whereas the other two are crucial developing markets in Asia and Africa. Both India and South Africa have been named among the promising emerging economies owing to their constant economic progress over the last few years ${ }^{2}$ During the period under study, the trade volume and capital flows of the above three countries have also increased (Zhenbo Hou et al., 2013; Deepak Mohanty, 2012; Karthikeyan \& Mohanasundaram, 2012). This research attempts to explore whether any of these stock market indices help in forecasting the other stock markets in the group and how these three markets relate to each other in both the long and short run.

The following observations motivated the researchers to undertake this study. First, South Africa is one of the major economies on the African continent. The JSE Africa Index Series is designed to represent the performance of South African companies, providing investors with a wide-ranging set of indices which measure the performance of the main industry segments of the South African market. The JSE All-Share Index represents 99 per cent of the full market capital value. ${ }^{3}$ A deeper understanding of the links between the Indian and South African stock markets would benefit the various stakeholders in these two emerging economies.

Second, India accounts for over 17.5 per cent of the world's population ${ }^{4}$ and its huge domestic market forms the basis of its rising global importance. India is expected to be one of the significant global economic powers in the years ahead. It hosts the second largest number of listed companies after the USA (Mohanasundaram \& Karthikeyan, 2012). The NIFTY index of the National Stock Exchange of India (NSE) was considered for the study because it is the largest stock exchange in India in terms of daily turnover and the number of trades ${ }^{5}$ The NSE is also the world's largest exchange by EOB (Electronic Order Book) number of trades. ${ }^{6}$ Thirdly, the influence of the US economy and its stock market on the global markets is well known and well documented, which is evident from the literature provided. Apart from this, the higher level of liquidity of the US Dollar enhances the prime position of the US stock market on the global stage. The trade volume between India and the US was $\$ 93$ billion in $2012 .^{7}$ The NASDAQ index was selected for the study because it is one of the major world stock indices.

\section{Literature review}

Among the European markets, Gilmore and McManus (2003) examine the bilateral and multilateral cointegration properties of the German stock market and three other Central European markets. The Johansen cointegration procedure indicates that there is no long-term relationship between the German and Central European markets, either individually or as a group. ChelleySteeley (2005) and Kearney and Poti (2006) examined the links among the various equity markets in the European markets. They found evidence in favour of a structural break in the process of market integration and established that the markets of Eastern Europe in particular are moving away from market segmentation. Ramaprasad Bhar and Shigeyuki Hamori (2008) investigated the co-movement in four large European equity markets over a sample period of nearly 30 years and found that the overall comovement in the equity markets was well established.

Among the Gulf and Middle East stock markets, Arouri and Nguyen (2010) analysed the timevarying features of cross-market correlations in selected Gulf markets and found that the conditional correlations between the markets are time-varying. The study also found that the comovements are still small within the Gulf region and insignificant between the Gulf stock markets and the world market. Purna Chandra Padhan (2007) analyses the dynamic relationships among Middle East stock markets and confirms that the Egyptian market plays a price discovery role.

Asian markets have also been studied extensively to discern the relationship and volatility existing between them and developed markets. Rajiv Menon, Subha and Sagaran (2009) considered whether the stock markets in the Indian subcontinent have any link to the major stock markets in China, Singapore, the USA and Hong Kong. The outcome confirmed that the Indian 
markets are related to some of the markets around the world. Gupta and Agarwal (2011) examined the correlation between the Indian stock market and five other major Asian economies (Japan, Hong Kong, Indonesia, Malaysia and Korea) and found a weak correlation among the stock exchanges. This offers a diversification benefit to institutional and international investors. Sharma and Bodla (2011) studied the links between the stock markets of India, Pakistan and Sri Lanka. The result suggests that the National Stock Exchange (India) Granger affects the Karachi Stock Exchange (Pakistan) and the Colombo Stock Exchange (Sri Lanka). Lamba (2004); Murali Batareddy et al. (2012); Hoque (2007) and Ibrahim (2005) found that the US market has an impact on the Asian markets.

For African markets, Sam Agyei-Ampomah (2011) examines the nature and extent of linkages among African stock markets and the relationships between the regional and global markets. He has found that the local index volatility is largely country-specific, which can be mitigated by cross-country diversification. Among the inter-continental studies, Queensly Jeyanthi (2010) examines the existence of cointegration and causality between the stock prices of BRIC (Brazil, Russia, India and China) countries and the US and Japan. The study found evidence of a long-run relationship between the BRIC countries and the US and Japan. In the short-run, the Indian stock market is dominated by the US market, while Russia is dominated by Japan. Chong, Drew and Veeraraghavan (2003) examined the relationship between Australia's stock market and the five largest international markets. They found that the Australian market has short- and long- run links with the United States market. Moreover, the US market was found to Granger-cause the Australian market. The studies of Maran Marimuthu (2010); Sowmya Dhanaraj et al. (2013); Valadkhani \& Chancharat (2008) use the Granger causality test to examine the presence of any Granger cause relationship between Asian and developed markets (the US and the UK). The study found that the developed markets, particularly the US, influence Asian markets.

Most of the above studies have accepted that there is a considerable level of integration among the stock markets. This implies that the benefit of international diversification is minimal owing to a higher level of integration among the stock markets. It is also noted that regional stock markets are experiencing more movement compared with other stock markets.

\section{Data and methodology}

\subsection{Research gap}

The majority of stock market cointegration studies have been carried out on advanced economies like the American and European markets. There are also a reasonable number of studies that compare various Asian stock markets. However, none of the studies reviewed by the researchers explore the stock market cointegration of Asian, African and US markets. This paper attempts to examine a special triangular relationship among the Indian, South African and US markets. Taking these factors into account, a detailed examination of cointegration and stock market interdependence among India, South Africa and US becomes highly relevant.

\subsection{Research questions and contribution}

The main research questions addressed in this study are as follows;

- What nature of association exists among the stock market movements of India, South Africa and the US?

- Are any stock market indices among the South African, Indian and American markets useful in forecasting the other stock market indices within the group?

- How are these stock-market indices related to each other in the long- and the short run?

\subsection{Methodology and theoretical framework}

The secondary market data used in this study consists of monthly time series stock-market indices of the National Stock Exchange - CNX NIFTY 50 (India), JSE Africa All share Index -JALSH 
(South Africa) and NASDAQ Composite (USA). The study is undertaken with the objective of finding whether there is Granger causality, and long-run and short-run relationships among these stock-market indices based on the data of the past decade. The study covers the period from April 2004 to March 2014 with total observations of 120 each.

Table 1

Data sources used in the study

\begin{tabular}{|l|l|l|}
\hline \multicolumn{1}{|c|}{ Index } & \multicolumn{1}{c|}{ Stock exchange } & \multicolumn{1}{c|}{ Data source } \\
\hline JSE Africa All Share Index - JALSH & Johannesburg Stock Exchange & www.jse.co.za \\
\hline CNX NIFTY 50 & National Stock Exchange & www.nseindia.com \\
\hline NASDAQ Composite & NASDAQ & www.bloomberg.com \\
\hline
\end{tabular}

The study used the monthly closing index value. The natural logarithm on these national stock indices was taken for the study.

$$
Y_{t}=\ln (Y)
$$

Where ' $Y_{t}$ ' is the natural log of monthly close value of indices at month' $t$ '.

\section{Normality test}

The data series of all the stock indices are tested for normality to know the nature of data distribution. The study uses the Jarque-Bera (JB) test to check whether the monthly closing values of the stock-market indices are normally distributed. The JB test is most commonly used to verify the nature of the distribution of time series data. This test statistic used in the JB test is as follows:

$$
J B=n\left[S^{2} / 6+(K-3)^{2} / 24\right]
$$

Where $\mathrm{n}=$ sample size, $\mathrm{S}=$ Skewness coefficient, and $\mathrm{K}=$ Kurtosis coefficient. Normally distributed variables have $\mathrm{S}=0$ and $\mathrm{K}=3$.

\section{Unit root test}

A unit root test examines whether a time series variable is stationary or non-stationary using an autoregressive model. The presence of a unit root in the data series is checked by employing the Augmented Dickey-Fuller (ADF) test and the Phillips-Perron (PP) test. Although there are many available tests for verifying the presence of a unit root, we used these tests because of their popularity and wide application. Time series data should be stationary for analysing i.e. whether the statistical properties of the series should be constant. The Augmented Dickey-Fuller (ADF) test controls for higher order correlation by adding lagged difference terms of the dependent variable to the right-hand side of the regression (Mohd. Aamir Khan et al, 2010). The Augmented Dickey Fuller specification used here is as follows:

$$
\Delta Y_{t}=b_{0}+\beta Y_{t-1}+\mu_{1} \Delta Y_{t-1}+\mu_{2} \Delta Y_{t-2}+\ldots . .+\mu_{p} \Delta Y_{t-p}+u_{t}
$$

Where, $Y_{t}$ represents the time series to be tested, $b_{0}$ is the intercept term, $\beta$ is the coefficient of interest in the unit root test, $\mu_{p}$ is the parameter of the augmented lagged first difference of $Y_{t}$ to represent the $\mathrm{p}^{\text {th }}$ order auto regressive process and $\mathrm{u}_{\mathrm{t}}$ is the white noise error term.

Phillips and Perron (1988) propose an alternative (nonparametric) method of controlling for serial correlation when testing for the unit root. This method estimates the non-augmented DF test equation and modifies the t-ratio of $\alpha$ coefficient so that the serial correlation does not affect the asymptotic distribution of the test statistic.

\section{Linear correlation}

Correlation analysis is used to know how two variables move in relation to each other. The linear correlation shows the strength of the association between dependent and explanatory variables.

$$
r=\left(n \sum x y-\left(\sum x\right)\left(\sum y\right)\right) / \sqrt{n\left(\sum x^{2}\right)-\left(\sum x\right)^{2}} \sqrt{n\left(\sum y^{2}\right)-\left(\sum y\right)^{2}}
$$

where, $\mathrm{X}$ and $\mathrm{Y}$ are the random variables. 


\section{Granger causality test}

The Granger-causality test is used to find out whether one time series helps in forecasting the other. A time series $X_{t}$ Granger causes another time series $Y_{t}$ if series $Y_{t}$ can be predicted with better accuracy by using past values of $X_{t}$ rather than by not doing so, other information being identical. The pre-condition for applying a Granger causality test is to ascertain the stationarity of the variables. In this study, the Granger causality study is undertaken to assess whether there is any potential predictability power of one stock-market's indices for the other. We use Granger causality under the VAR framework to capture the degree and direction of causality between the stock market indices.

The optimum lag length for variables is found by the vector autoregression (VAR) lag order selection method. There are six criteria: the log likelihood value $(\log \mathrm{L})$; the sequential modified likelihood ratio (LR) test statistic; the final prediction error $(\mathrm{F} \& \mathrm{E})$; the Akaike information criteria (AIC); the Schwarz information criterion (SC); and the Hannan-Quin information criterion (HQ) for choosing the optimal lag length. Apart from the LR statistic, all the others are minimizing functions of lag length. The choice of optimum lag length is the minimum of the individual criterion function and is symbolized as *. The Granger causality test is performed as follows and the similar equations are framed for all the combinations for causality testing.

$$
\Delta J_{t}=\alpha_{1}+\beta_{11} \Delta J_{t-1}+\beta_{12} \Delta J_{t-2}+\beta_{1 n} \Delta J_{t-n}+\gamma_{11} \Delta N_{t-1}+\gamma_{12} \Delta N_{t-2}+\ldots+\gamma_{1 n} \Delta N_{t-n}+u_{1}
$$

Where, $\Delta J_{t}$ is the first difference at time ' $\mathrm{t}$ ' of JALSH where the series is non-stationary, ' $\alpha$ ' is the constant, ' $n$ ' is a positive integer, $\beta_{j}$ and $\gamma_{j}$ are parameters, $\mathrm{N}$ and $u_{t}$ are error terms.

\section{Cointegration approach}

The cointegration test is used to check the presence of a long-run relationship among the selected economic and financial variables. Gonzalo and Granger (1995) point out that the evidence of cointegration among national stock-market indices implies equilibrium constraints, which prohibit the cointegrated stock-market indices from diverging too much in the long run. This is because the indices share common stochastic trends or the same driving forces over the time period. The absence of cointegration indicates that within the stock market there is no long-run relationship. Many prior studies show that a extensive sample period is necessary to discover a co-integration relationship in the long run (Bo Sjo, 2008; Hendry \& Juselius, 2000). Hargreaves (1994) as cited by Ahking (2002) concludes that the Johansen's method is the best cointegration method if the sample size is fairly large (about 100 or more observations).

As the stock-market indices are integrated in the same order i.e. I(1), the Johansen (1988) Maximum Likelihood (ML) is used to test the presence of a stable long-run relationship between JALSH, NIFTY and NASDAQ. The Johansen approach produces two statistics, trace and maximum eigenvalue. These statistics are used to determine the number of cointegrating vectors. If any conflict arises in the result produced by the $\lambda_{\text {trace }}$ test and the $\lambda_{\max }$ test, the study can progress based on $\lambda_{\max }$ (Nguyen, 2011).

\section{Vector autoregression model}

When there is no cointegration vector as per the maximum Eigen value test, only unrestricted VAR must be used for studying the short-run relationship among the stock indices. The vector autoregression (VAR) model is used to capture the linear interdependencies among multiple time series. It is commonly used for forecasting systems of interrelated time series and for analysing the dynamic impact of random disturbances on the system of variables. In a VAR, each variable is explained by its own lagged values and the lagged values of all the other variables in the system. The mathematical representation of VAR is:

$$
=A_{1} Y_{t-1}+\ldots+A_{p} Y_{t-p}+B x_{t}+e_{t}
$$

Where $Y_{t}$ is a ' $k$ ' vector of endogenous variables, $x_{t}$ is a ' $d$ ' vector of exogenous variables, $A_{1} \ldots$ $A_{p}$, 'B' are matrices of coefficients to be estimated, and $e_{t}$ is a vector of innovations that may be 
concurrently correlated but are uncorrelated with their own lagged values and uncorrelated with all of the right-hand side variables (Referred from EViews 7 Users Guide).

\section{Results and discussion}

The Normality test has been conducted for the JALSH, NIFTY and NASDAQ stock-market indices. Jarque-Bera statistics are used to test the normality of each data series. Table 2 shows the results, along with the descriptive statistics. The skewness value 0 and the kurtosis value 3 indicate that the variables are normally distributed. The standard deviation of NIFTY (0.39) and JALSH (0.38) states that these stock-market indices are comparatively more volatile than NASDAQ (0.23). The probability of 0.00 indicates that the null hypothesis of normality assumption is rejected in the case of JALSH and NIFTY. The frequency distribution of NASDAQ is found to be normal, unlike that of JALSH and NIFTY.

Table 2

Descriptive statistics of stock-market indices

\begin{tabular}{|c|c|c|c|}
\hline Statistic & JALSH & NIFTY & NASDAQ \\
\hline Mean & 10.15 & 8.32 & 7.80 \\
\hline Median & 10.24 & 8.49 & 7.78 \\
\hline Maximum & 10.77 & 8.81 & 8.37 \\
\hline Minimum & 9.22 & 7.30 & 7.23 \\
\hline Std. Dev. & 0.38 & 0.39 & 0.23 \\
\hline Skewness & -0.74 & -0.99 & 0.29 \\
\hline Kurtosis & 2.92 & 2.85 & 3.24 \\
\hline Jarque-Bera & 10.94 & 19.83 & 1.93 \\
\hline Probability & 0.00 & 0.00 & 0.38 \\
\hline Observations & 120.00 & 120.00 & 120.00 \\
\hline Result & Not normal & Not normal & Normal \\
\hline
\end{tabular}

After testing for normality, it is essential to verify whether or not the data used in the study has a unit root. The data should be stationary (no unit root). The easiest and simplest way to check for stationarity is to plot a time series data graph and note the trends in mean and variance. Time series data is believed to have stationarity if the mean and variance of the time series are constant over the time period. The data series graphs are shown below of the stock-market indices which specify that stock-market indices are not moving around the constant mean and variance. All three stock-market indices appear to display a trend in the mean as they have a clear upward slope, which is an indication of no constant mean. In addition, the vertical fluctuations are not similar at different points of time series, indicating that variance is not constant. Thus we can say all the three indices are non-stationary in the present form.

Figure 1

JALSH index time series

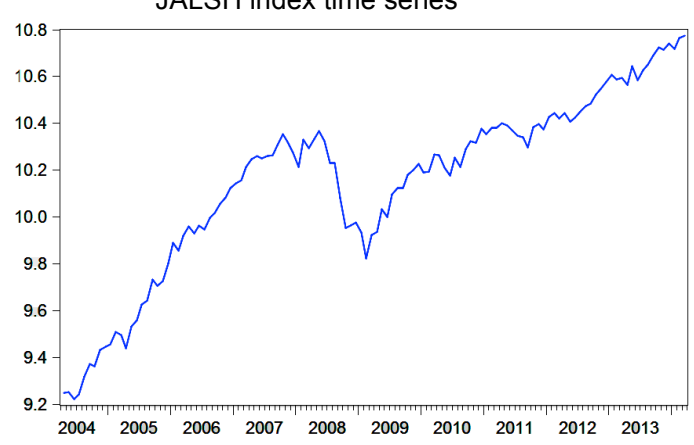

Figure 2

NIFTY index time series

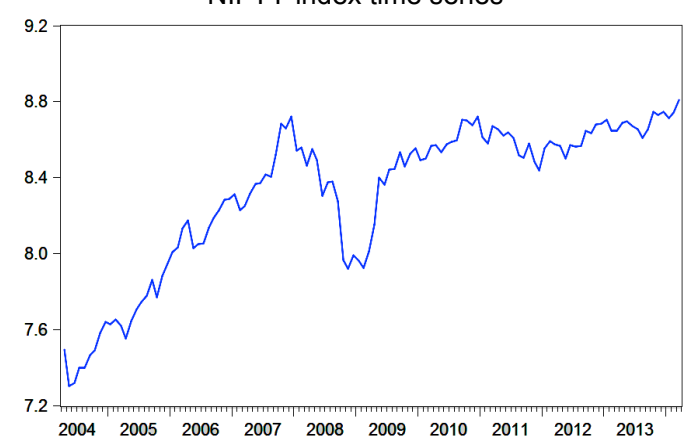


Figure 3

NASDAQ index time series

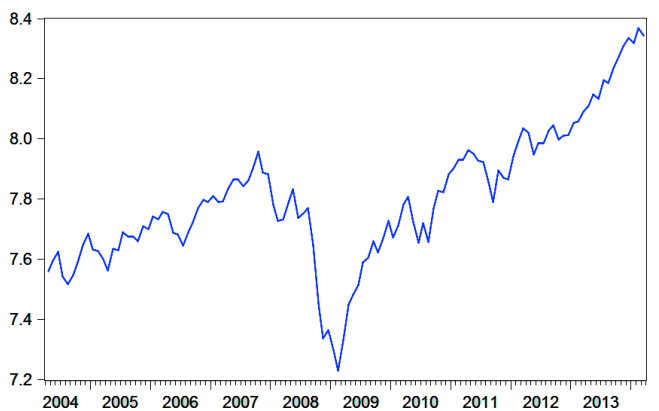

Unit root tests are applied in addition to the graphical inspection to decide the real nature of time series. For this, the Augmented Dickey-Fuller (ADF) and the Phillips-Perron (PP) tests are carried out to verify the stationarity of the time series data. The tests are carried out with the null hypothesis of non stationarity (unit root) for each data series and the results indicate all the three data series are at the non-stationary level and become stationary after first-order difference.

Table 3

Unit root test

\begin{tabular}{|c|c|c|c|c|c|}
\hline \multicolumn{6}{|c|}{ Augmented Dickey-Fuller (ADF) test - Intercept and trend } \\
\hline \multirow{2}{*}{ Data series } & \multicolumn{2}{|c|}{ At Level } & \multicolumn{2}{|c|}{ At $1^{\text {st }}$ order difference } & \multirow{2}{*}{ Resul } \\
\hline & t-statistic & Prob. & t-statistic & Prob. & \\
\hline JALSH & -2.6927 & 0.2417 & -3.8861 & $0.0159^{*}$ & $\mathrm{I}(1)$ \\
\hline NIFTY & -2.1404 & 0.5178 & -10.6953 & $0.0000^{*}$ & $\mathrm{I}(1)$ \\
\hline NASDAQ & -1.7475 & 0.7237 & -9.2389 & $0.0000^{*}$ & $\mathrm{I}(1)$ \\
\hline \multicolumn{6}{|c|}{ Phillips and Peron (PP) test - Intercept and trend } \\
\hline \multirow{2}{*}{ Data series } & \multicolumn{2}{|c|}{ At Level } & \multicolumn{2}{|c|}{ At $1^{\text {st }}$ order difference } & \multirow{2}{*}{ Result } \\
\hline & t-statistic & Prob. & t-statistic & Prob. & \\
\hline JALSH & -2.2051 & 0.4821 & -11.4927 & $0.0000^{*}$ & $\mathrm{I}(1)$ \\
\hline NIFTY & -2.2935 & 0.4339 & -10.6940 & $0.0000^{*}$ & $\mathrm{I}(1)$ \\
\hline NASDAQ & -1.6919 & 0.749 & -9.2389 & $0.0000^{*}$ & $\mathrm{I}(1)$ \\
\hline
\end{tabular}

* Implies rejection of null hypothesis at 5 per cent and therefore the data series is stationary

Prior to econometric analysis, a correlation test is carried out between JALSH, NIFTY and NASDAQ, as this gives preliminary insight into the existence of comovement among the time series variables. Table 4 displays the correlation coefficients between the three stock-market indices.y

Table 4

Correlation matrix between JALSH, NIFTY and NASDAQ

\begin{tabular}{|l|c|c|c|}
\hline \multicolumn{1}{|c|}{ Indices } & JALSH & NIFTY & NASDAQ \\
\hline JALSH & 1 & - & - \\
\hline NIFTY & 0.9211 & 1 & - \\
\hline NASDAQ & 0.8723 & 0.7228 & 1 \\
\hline
\end{tabular}

JALSH and NIFTY have a very high positive association (92.11 per cent), which indicates that both markets are following almost the same trend over the applicable period. In other words, a strong linear trend exists between JALSH and NIFTY. This is because they may be sharing a common driving force. JALSH has a high positive correlation with NASDAQ (87.23 per cent) in comparison with NIFTY with NASDAQ (72.28 per cent). Overall, the correlation matrix shows that there is a strong correlation among these three stock markets. 
The high correlation among the stock market indices motivated the researchers to examine whether the past of one stock market index improves the prediction of the present and future of other stock market indices. This is examined with the Granger causality test. The results of Granger Causality tests are highly sensitive to the order of lags. To choose the optimum number of lags, we used VAR lag order selection criteria. Table 5 shows the result.

Table 5

VAR Lag order selection

\begin{tabular}{|c|c|c|c|c|c|c|}
\hline Lag & LogL & LR & FPE & AIC & SC & HQ \\
\hline 1 & 571.9703 & 862.9755 & $9.12 \mathrm{e}-09^{\star}$ & $-9.999470^{*}$ & $-9.708202^{*}$ & $-9.881293^{*}$ \\
\hline 5 & 604.8371 & $24.08732^{*}$ & $9.70 \mathrm{E}-09$ & -9.943519 & -8.778448 & -9.470813 \\
\hline
\end{tabular}

* Indicate the lag length to be selected

Here, the Final Prediction Error criterion (FPE), the Akaike information criterion (AIC), the Schwarz information criterion (SC) and the Hannan-Quinn information criterion (HQ) support a lower-order lag length of one month. On the other hand, the sequential modified LR test statistic (LR) shows a higher-order lag length of five months. As empirical studies generally prefer lowerorder lags, and a lag length of one is supported by most of the criteria, subsequent analyses are based on one lag length.

Table 6

VAR Granger causality / Block xxogeneity Wald tests

\begin{tabular}{|c|c|c|c|}
\hline Null Hypothesis & F-Statistics & p-value & Decision on $\mathrm{H}_{\mathrm{o}}$ \\
\hline \multicolumn{4}{|c|}{ Dependent variable: JALSH } \\
\hline NIFTY does not Granger cause JALSH & 0.6280 & 0.4281 & Not Rejected \\
\hline NASDAQ does not Granger cause JALSH & 1.0716 & 0.3006 & Not Rejected \\
\hline \multicolumn{4}{|c|}{ Dependent variable: NIFTY } \\
\hline JALSH does not Granger cause NIFTY & 4.4232 & 0.0355 & Rejected \\
\hline NASDAQ does not Granger cause NIFTY & 1.7389 & 0.1873 & Not Rejected \\
\hline \multicolumn{4}{|c|}{ Dependent variable: NASDAQ } \\
\hline JALSH does not Granger cause NASDAQ & 0.8113 & 0.3677 & Not Rejected \\
\hline NIFTY does not Granger cause NASDAQ & 0.4869 & 0.4853 & Not Rejected \\
\hline
\end{tabular}

The Granger causality test result indicates that the null hypothesis 'JALSH does not Granger cause NIFTY' is rejected, but all other null hypotheses are not. This indicates that the JALSH index can be used to forecast the NIFTY index as well as its own lags.

The correlation and Granger causality need to further verify for long-term movements among the stock-market indices by the cointegration test. As the time series data for the three indices are non-stationary at level and become stationary at first-order difference, Johansen's cointegration test is applied to examine the long-term relationship between JALSH, NIFTY and NASDAQ.

Table 7

Johansen cointegration test

\begin{tabular}{|c|c|c|c|c|}
\hline \multicolumn{5}{|c|}{ Unrestricted cointegration rank test (Trace) } \\
\hline Hypothesized no. of CE(s) & Eigenvalue & Trace statistic & $\begin{array}{c}0.05 \\
\text { Critical value }\end{array}$ & Prob $^{\star *}$ \\
\hline None * & 0.146064 & 33.11721 & 29.79707 & 0.0200 \\
\hline At most 1 & 0.114905 & 14.48517 & 15.49471 & 0.0705 \\
\hline At most 2 & 0.000695 & 0.082088 & 3.841466 & 0.7745 \\
\hline \multicolumn{5}{|c|}{ Unrestricted cointegration rank test (Maximum Eigenvalue) } \\
\hline Hypothesized no. of CE(s) & Eigenvalue & Max-Eigen statistic & $\begin{array}{c}0.05 \\
\text { Critical value }\end{array}$ & Prob $^{\star *}$ \\
\hline None & 0.146064 & 18.63204 & 21.13162 & 0.1080 \\
\hline At most $1 *$ & 0.114905 & 14.40308 & 14.26460 & 0.0475 \\
\hline At most 2 & 0.000695 & 0.082088 & 3.841466 & 0.7745 \\
\hline
\end{tabular}

${ }^{*}$ Rejection of null hypothesis at 0.05 level; ${ }^{* *}$ Mackinnon, Haug \& Michelis (1999) p-values 
In Johansen's cointegration approach, the trace statistic shows the presence of 1 cointegration equation and the Max-eigenvalue statistic indicates no cointegration at 0.05 level. As the eigenvalue statistic says there is no cointegration equation between the variables, it is concluded that there is no long-run relationship between the stock-market indices. We applied unrestricted VAR in this study to estimate the short-run relationship among the stock-market indices.

Table 8

Vector autoregression estimates (least squares) with $\mathrm{P}$-value

\begin{tabular}{|l|l|c|c|c|}
\hline Variables/lag & \multicolumn{1}{|c|}{ Parameter } & JALSH & NIFTY & NASDAQ \\
\hline \multirow{4}{*}{ JALSH(-1) } & Coefficient & 0.933409 & 0.159178 & 0.048227 \\
\cline { 2 - 5 } & Standard errors & -0.04756 & -0.07569 & -0.05354 \\
\cline { 2 - 5 } & t-statistics & {$[19.6268]$} & {$[2.10316]$} & {$[0.90077]$} \\
\cline { 2 - 5 } & p-value & $0.0000^{*}$ & $0.0362^{*}$ & 0.3683 \\
\hline \multirow{5}{*}{ NIFTY(-1) } & Coefficient & 0.031568 & 0.848206 & -0.031294 \\
\hline & Standard errors & -0.03983 & -0.06339 & -0.04484 \\
\cline { 2 - 5 } & t-statistics & {$[0.79251]$} & {$[13.3804]$} & {$[-0.69785]$} \\
\cline { 2 - 5 } & p-value & 0.4286 & $0.0000^{*}$ & 0.4857 \\
\hline \multirow{5}{*}{ NASDAQ(-1) } & Coefficient & 0.033034 & -0.066969 & 0.967129 \\
\cline { 2 - 5 } & Standard errors & -0.03191 & -0.05078 & -0.03593 \\
\cline { 2 - 5 } & t-statistics & {$[1.03518]$} & {$[-1.31869]$} & {$[26.9205]$} \\
\cline { 2 - 5 } & p-value & 0.3013 & 0.1881 & $0.0000^{*}$ \\
\hline
\end{tabular}

* Significant at 5 per cent level

The VAR estimate shows that JALSH and NASDAQ are the functions of their own lag JALSH (1) and NASDAQ (-1) respectively. However, NIFTY is a function of both its own lag NIFTY (-1) and JALSH (-1). This shows that JALSH and NASDAQ are not affected by other indices apart from their own past lag. However, NIFTY is defined by its own past lag and the past lag of JALSH. In the short run, the influence of JALSH over NIFTY is quite unexpected, even though they are highly correlated.

\section{Conclusion}

This paper empirically investigates the relationship and the degree of cointegration between the South African, Indian and US stock market indices. All three stock market indices are found to be non-stationary, and become stationary after the first differencing. There is a strong positive correlation among the variables. The correlation between the time-series variables of NIFTY and JALSH is very high. The correlation is further verified for the direction of influence by the Granger causality test, which found that JALSH Granger causes NIFTY at the 5 per cent level. The maximum Eigenvalue statistic indicates that there is no long-run relationship between any of these stock markets. In other words they are not cointegrated in the long run. To examine the short-run relationship between the stock markets, a Vector autoregression test is applied, which indicates that the South African and US market indices are not predictable by other stock markets' movements. However, Indian stock market index predictability could be improved by including South African stock market index lags. Thus the economic intuition of this research is, regardless of strong correlation, that there is no evidence of long-run relationship between these three stock markets. As the stock market indices are independent in the long run, these markets offer the possibilities of investment diversification for international investors.

\section{Endnotes}

1 WFE 2013 Market highlights, world federation of exchanges, 28 January 2014. Available at: http://www.world-exchanges. org/files/2013 WFE Market Highlights.pdf

2 The world's fastest-growing economies will not be a cause for concern unless they slow down, Available at: http://www.bloomberg.com/bw/articles/2014-07-21/brics-summit-a show -of-economic-might-is-nothing-to-fear. 
3 FTSE Group, FTSE/JSE All share index fact sheet, 31 ${ }^{\text {st }}$ March 2014.

4 en.wikipedia.org/wiki/Demographics_of_India [accessed 2014-04-17].

5 Leadership through change, National Stock Exchange of India Ltd. Available at http://www.nseindia.com/content/press/leadership.pdf [accessed 2014-04-23]

6 WFE 2013 market highlights, World federation of Exchanges, 28 January 2014. Available at: http://www.worldexchanges.org/files/2013_WFE_Market_Highlights.pdf

7 Office of the United States Trade Representative. Available at: http://www.ustr.gov/countries-regions/south-centralasia/india [accessed 2014-04-09].

\section{References}

AHKING, F.W. 2002. Model mis-specification and Johansen's co-integration analysis: An application to the US money demand. Journal of Macroeconomics, 24:51-66.

ANDJELIC, G. \& DJAKOVIC, V. 2012. Financial market co-movement betweentTransition economies: A case study of Serbia, Hungary, Croatia and Slovenia. Acta Polytechnica Hungarica, 9(3).

AROURI, MOHAMED EL HEDI \& NGUYEN, D.K. 2010. Time-varying characteristics of cross-market linkages with empirical application to Gulf stock markets. Managerial Finance, 36(1):57-70.

BO SJO. 2008. Testing for unit roots and cointegration. Lectures in Modern Econometric Time series Analysis. Available at: www.iei.liu.se/nek/ekonometrisk-teori-7-5-hp-730a07/labbar/1.233753/dfdistab7b.pdf [accessed 2014-02-04].

CHELLEY-STEELEY, P.L. 2005. Modelling equity market integration using smooth transition analysis: A study of Eastern European stock markets. Journal of International Money and Finance, 24:818-831.

CHONG, L., DREW, M. \& VEERARAGHAVAN, M. 2003. Stock market interdependence: Evidence from Australia. Pacific Accounting Review, 15(2):51-76.

DEEPAK MOHANTY. 2012. Global capital flows and the Indian economy - Opportunities and challenges. BIS central bankers' speeches. Technical and Entrepreneurship Festival of IITK, Kanpur. pp. 1-12.

DICKEY, D.A. \& FULLER, W.A. 1979. Distribution of the estimators for autoreressive time series with a unit root. Journal of the American Statistical Association, 74(366):427-431.

DORODNYKH, E. 2014. Determinants of stock exchange integration: Evidence in worldwide perspective. Journal of Economic Studies, 41(2):292-316.

GILMORE, C.G. \& McMANUS, G.M. 2003. Bilateral and multilateral cointegration properties between the German and Central European equity markets. Studies in Economics and Finance, 21(1):40-53.

GONZALLO, J. \& GRANGER, C.W.J. 1995. Estimation of common long-memory components in cointegrated systems. Journal of Business and Economic Statistics, 13(1):27-35.

GUPTA, N. \& AGARWAL, V . 2011. Comparative study of distribution of Indian stock market with other Asian markets. International Journal of Enterprise Computing and Business Systems, 1(2):1-20.

HARGREAVES, C.P. 1994. Nonstationary time series analysis and cointegration. Oxford University Press Inc.: New York.

HENDRY, D.F. \& JUSELIUS, K. 2000. Explaining cointegration analysis: Part II. Discussion Papers 00-20, Department of Economics, University of Copenhagen.

HOQUE, HAFIZ AL ASAD BIN. 2007. Co-movement of Bangladesh stock markets: Cointegration and error correction approach. Managerial Finance, 33(10):810-820.

IBRHIM, M.H. 2005. International linkage of stock prices: The case of Indonesia. Management Research News, 28(4):93-115.

JANAK RAJ \& SARAT DHAL. 2008. Integration of India's stock market with global and major regional. BIS papers, No 42.

JOHANSEN, S. 1988. Statistical analysis of cointegrating vectors. Journal of Economic Dynamics and Control, 12:213-254.

KARTHIKEYAN, P. \& MOHANASUNDARAM, T. 2012. FII flows and Indian equity market performance. Asian Journal of Managerial Science, 1(1):12-16, ISSN:2249-6300.

KEARNEY, C. \& POTI, V. 2006. Correlation dynamics in European equity markets. Research in International Business and Finance, 20:305-321.

LAMBA A.S. 2004. An analysis of the dynamic relationships between South Asian and developed equity markets. NSE research working papers - Paper 83 . 
MACKINNON, J.G., HAUG, A.A. \& MICHELIS, L. 1999. Numerical distribution functions of likelihood ratio tests for cointegration. Journal of Applied Econometrics, 14(5):563-577.

MARAN MARIMUTHU. 2010. The co-movements of the regional stock markets and some implications on risk diversification. The IUP Journal of Applied Economics, IX(2):61-80.

MOHANASUNDARAM, T. \& KARTHIKEYAN, P. 2012. Impact of institutional investments and macroeconomic variables in the Indian equity market. International Research Journal of Finance and Economics, 94:69-78.

MURALI BATAREDDY, ARUN KUMAR GOPALASWAMY \& CHIA-HSING HUANG. 2012. The stability of long-run relationships: A study on Asian emerging and developed stock markets (Japan and US). International Journal of Emerging Markets, 7(1):31-48.

PADHAN, P.C. 2007. The nexus between stock market and economic activity: An empirical analysis for India. International Journal of Social Economics, 34(10):741-753.

PHILLIPS, C.B. \& PERRON, P. 1988. Testing for a unit root in time series regression. Biometrika, 75(2):335-346.

QUEENSLY JEYANTHI, B.J. 2010. Who moves BRIC stock markets: US or Japan? The IUP Journal of Applied Finance, 16(5):61-71.

RAJA SETHU DURAI, S. \& BHADURAI, S.N. 2011. Correlation dynamics in equity markets-evidence from India. Research in International Business and Finance, Elsevier, 25(1):64-74. Available at: http://ideas.repec.org/a/eee/riibaf/v25y2011i1p64-74.html [accessed 2014-04-17].

RAJIV MENO, N., SUBHA, M.V. \& SAGARAN, S. 2009. Cointegration of Indian stock markets with other leading stock markets. Studies in Economics and Finance, 26(2):87-94.

RAMAPRASAD BHAR \& SHIGEYUKI HAMORI. 2008. A new approach to analysing comovement in Europen equity markets. Studies in Economics and Finance, 25(1):4-20.

SAM AGYEI-AMPOMAH 2011. Stock market integration in Africa. Managerial Finance, 37(3):242-256.

SHARMA, G.D. \& BODLA, B.S. 2011. Inter-linkages among stock markets of south Asia. Asia-Pacific journal of Business Administration, 3(2):132-148.

SOWMYA DHANARAJ., GOPALSWAMY, A.K. \& SURESH BABU, M. 2013. Dynamics interdependence between US and Asian markets: An empirical study. Journal of Financial Economic policy, 5(2):220-237.

TEHRANI, A.E. 2011. A comparative analysis of Tehran stock exchange and selected stock markets: Evidence from a correlation matrix. Institute of Graduate studies and Research, Eastern Mediterranean University. Unpublished masters.

VALADKHANI, A. \& CHANCHARAT, S. 2008. Dynamic linkages between Thai and international stock markets. Journal of Economic Studies, 35(5):425-441.

ZHENBO HOU, KEANE, J., KENNAN, J., MASSA, I. \& TE VELDE, D.W. 2013. The changing nature of private capital flows to sub-Saharan Africa. Overseas Development Institute, Working Paper, 376:1-42. 